\title{
Addition of sedimentary rock to kaolinitic clays: influence on sintering process
}

\section{(Adição de rocha sedimentar às argilas cauliníticas: influência no processo de sinterização)}

\author{
A. E. Souza, S. R. Teixeira, G. T.A. Santos, E. Longo \\ Departamento de Física, Química e Biologia, Universidade Estadual Paulista - FCT/UNESP \\ Rua Roberto Simonsen, 305, Presidente Prudente, SP, Brasil, 19060-080 \\ agda_pb@ig.com.br
}

\begin{abstract}
The physical and mechanical properties of clay-based ceramic probes with sedimentary rock added as the non-plastic component were evaluated. Samples were prepared with $0,20,40,60$ and $80 \mathrm{wt} . \%$ of rock added to the clay material. Pressed ( 7 ton) probes were sintered at 500, 800, 900, 1000, 1100 and $1200{ }^{\circ} \mathrm{C}$ and submitted to X-ray diffraction analysis and technological characterization. The X-ray diffraction results showed that the sedimentary rock had micaceous clay minerals, while the clay material had kaolinite as the main phases. Thermal analysis and X-ray diffraction showed reactions that indicated transformation (inversion of quartz), decomposition (loss of hydroxides) and phase formation (mullite) during heat treatment of the samples. The technological tests showed that the addition of sedimentary rock improved some properties of the sintered material, aided by the presence of fluxes However, the presence of quartz in the rock hampered the formation of the mullite phase. The formation of new phases and transformations occurring during the heating and cooling of the samples helped explain the technological properties of ceramic materials.
\end{abstract}

Keywords: clay, sedimentary rock, fluxes, sintering, mullite.

\section{Resumo}

Foram avaliadas, durante o processo de sinterização, as propriedades mecânicas de peças cerâmicas a base de argila com adição de rocha sedimentar. Foram preparados corpos de prova com 0, 20, 40, 60 e 80\% em peso de rocha adicionada ao material argiloso. As peças foram sinterizadas nas temperaturas de 500, 800,900, 1000, 1100 e $1200{ }^{\circ} \mathrm{C}$ e, posteriormente, submetidas à análise de difração de raios $X$ e a ensaios tecnológicos Os resultados de difração de raios X mostram que a rocha sedimentar apresenta argilominerais micáceos enquanto o material argiloso possui a caulinita como fase principal. Técnicas de análises térmicas e difração de raios $X$ das diferentes misturas mostram reações que indicam transformação (inversão do quartzo), decomposição (perda de hidróxidos) e formação de fase (mulita) durante o aquecimento das amostras. Os ensaios tecnológicos mostram que a adição da rocha sedimentar melhora algumas propriedades do material sinterizado, auxiliada pela presença de fundentes. Entretanto, a presença de quartzo na rocha dificulta a formação da fase mulita. A formação de novas fases e as transformações ocorridas no aquecimento e resfriamento das amostras ajuda explicar as propriedades tecnológicas dos materiais cerâmicos.

Palavras-chave: argila, rocha sedimentar, fundentes, sinterização, mulita.

\section{INTRODUCTION}

The raw material of the red ceramic industry is heterogeneous in nature, and therefore, the incorporation of other matter of various types and origins is allowed, if the properties of the raw are kept within the limits established by technical standards. A clayey material of high plasticity requires mixing with non-plastic agents to obtain an adequate particle size distribution for the processing of the product with the desired final characteristics [1].

During the sintering of a ceramic material, there are reactions that define the microstructure and final properties of the material. These reactions occur during heating and cooling and are facilitated by the formation of a liquid phase that causes the densification of the material. When many components are involved, a very large number of phases may form, leading to the term multiphase ceramics $[2,3]$.

One important phase formed during sintering of the clay minerals is mullite. Mullite is a stable phase at high temperature. There are two types of mullite formed: mullite $I$, which is recognized starting at $950{ }^{\circ} \mathrm{C}$ and increases up to about $1100{ }^{\circ} \mathrm{C}$, manifesting in the form of small lamellar crystals, which are zoned due to their non-chemical homogeneity with a composition close to $3 \mathrm{Al}_{2} \mathrm{O}_{3} \cdot 2 \mathrm{SiO}_{2}$, or $3: 2$ mullite; and mullite II, which develops starting at $1200^{\circ} \mathrm{C}$, appearing in the form of relatively well-developed prismatic crystals, more chemically homogeneous with a composition close to $2 \mathrm{Al}_{2} \mathrm{O}_{3} \cdot \mathrm{SiO}_{2}$, or 2:1 mullite. Some authors assert that 
another form of type 3:2 mullite exists, which comes from the intermediate spinel phase, i.e., from the decomposition of metakaolinite, and is designated as a "cubic mullite" $[4,5]$. Therefore, the mullite structure has two crystalline forms that depend on the $\mathrm{Si} / \mathrm{Al}$ ratio of the material. Mullite with deficiencies in aluminum has a tetragonal structure, while that with higher amounts of aluminum shows an orthorhombic structure. The orthorhombic crystal structure features a split peak (doublet) in the X-ray diffraction pattern close to $26^{\circ}(2 \theta)[6]$.

The temperature of new phases and liquid phase formation can be reduced by the addition of fluxes or mineralizers. Besides the natural fluxes, such as feldspars and micas, various types of waste have been used as additives or fluxes in the production of ceramic material. The formation of the liquid phase is important because it fills the microstructures, reduces porosity and increases the density of the material. Sedimentary rocks of the western region of S. Paulo State, Brazil, contain clay minerals, with a predominance of the mica group (illite). Thus, these materials exhibit a chemical composition with large amounts of potassium, giving them a flux character [7].

Sánchez-Muñoz et al. (2002) [8] examined a series of clays and found that illitic clays act as fluxes. However, according to these authors, clay mineralogy does not completely define the ability of a sample to melt. It is the contact surface between the particles that characterizes the firing behavior, influencing the reactivity. Thus, clays with finer particles have a flux character, where the formation of this binding phase is directly related to the existence of contacts between the clay particles, which starts the melting process. Thus, the open porosity of a ceramic material, which is due to dehydration and subsequent transformations at high temperatures, can be closed in the presence of sufficient small-size particles. Vieira et al. (2004) [9] also used illitic flux clay in ceramics as an alternative to reduce the porosity of the clay products with predominantly kaolinitic raw material. According to this study, an increase in the concentration of clay flux results in an increase in mechanical strength and reduction in water absorption. Besides contributing to a more effective sintering process through a liquid phase, the incorporation of clay flux reduces weight loss during firing.

This paper reports the characterization of a high-plasticity clay material and a sedimentary rock, from western S. Paulo State, Brazil and the effects caused by the incorporation of rock in the sintering process and the formation of mullite in this plastic clay. We used a combination of techniques to characterize the materials and identify the phases formed during the sintering process, namely fluorescence and X-ray diffraction, textural analysis (pipette method), thermal analysis (differential thermal analysis (DTA) and thermogravimetry and differential thermogravimetry (TG/ DTG)) and physical and mechanical tests (linear shrinkage, water absorption, bulk density, apparent porosity and flexural strength).

\section{EXPERIMENTAL}

A clayey material obtained from the ceramic company Cerâmica Romana in Presidente Epitácio city in western S. Paulo State and a sedimentary rock removed from the outcrops and slopes on the sides of the Raposo Tavares Highway in this same region were analyzed. The clayey material and the rock were dried in an oven at $110{ }^{\circ} \mathrm{C}\left( \pm 10^{\circ} \mathrm{C}\right)$ for 24 $\mathrm{h}$, ground in a Marconi knife mill (MA-880) and passed through a sieve of $0.125 \mathrm{~mm}$ (120 mesh). The sedimentary rock was added to the clay material at $0,20,40,60$ and $80 \mathrm{wt} . \%$ concentrations to make the probes. The mixtures were placed in closed plastic bottles and homogenized in a ball mill (without balls) for $8 \mathrm{~h}$. After oven-drying and cooling in desiccators, distilled water was added to $13 \mathrm{wt} \%$ to obtain the appropriate plastic mass for compression. The wet samples were placed in a sealed plastic bag and kneaded regularly for $48 \mathrm{~h}$ to get a better homogenization of the moisture. The moist plastic mass was passed through a sieve of $0.84 \mathrm{~mm}(20 \mathrm{mesh})$ to reduce agglomerates and obtain a better distribution of grains. Prismatic specimens $(\sim 60 \times 20$ $\times 5 \mathrm{~mm}^{3}$ ) were pressed using a manual hydraulic press with steel matrix (for triplicate probes) and a uniaxial pressure of 19 MPa during compression, per specimen.

To identify the chemical components of the samples, quantitative chemical analysis was performed by X-ray fluorescence spectrometry. The minerals present in the clay material and rock were determined by X-ray diffraction (XRD) using a Rigaku instrument, DMAC2500PC with copper $\kappa-\alpha$ radiation and sweep from $2 \theta=5$ to $75^{\circ}$. Powdered samples and their clay fractions saturated with potassium or magnesium, oriented on glass slides, were analyzed. In addition, the XRD technique was used to monitor and identify the sequence of phase transformations in these specimens, sintered at different temperatures.

Differential thermal analysis (DTA) was performed to determine the sample reaction temperatures. The equipment used was a model DTA-1600, TA Instruments, with an alumina sample pan, air atmosphere, and heating rate of $20^{\circ} \mathrm{C} /$ min, from 25 to $1300{ }^{\circ} \mathrm{C}$. Thermogravimetric analysis (TG), used to monitor the loss of mass during heating of the sample was carried out in a TG-209/FTIR Netzsch instrument, with synthetic air atmosphere and heating rate of $10^{\circ} \mathrm{C} / \mathrm{min}$ from 25 to $1000{ }^{\circ} \mathrm{C}$.

The specimens were submitted to the sintering process at temperatures of $500,800,900,1000,1100$ and $1200{ }^{\circ} \mathrm{C}$ using an EDG oven (model 3000), with a heating rate of $10{ }^{\circ} \mathrm{C} / \mathrm{min}$ and $2 \mathrm{~h}$ burning step in an air atmosphere. After cooling in a desiccator, the specimens were measured, weighed and subjected to physical and mechanical tests for determinations of linear shrinkage, water absorption, apparent density, apparent porosity and flexural strength at three points (EMIC model DL 2000 testing machine) [2]. The sample fired at $500{ }^{\circ} \mathrm{C}$ was tested only for flexural strength. The results presented below represent the average values for six probes, for each sample. 


\section{RESULTS}

\section{Characterization: raw materials}

The percentages of clay, silt and sand, for both raw materials, determined by the pipette method (texture), are shown in Table I.

Table I - Textural analysis.

[Tabela I - Análise textural.]

\begin{tabular}{cccc}
\hline Granulometry & $\begin{array}{c}\text { Fraction } \\
(\%)\end{array}$ & $\begin{array}{c}\text { Clayey } \\
\text { Material }\end{array}$ & $\begin{array}{c}\text { Sedimentary } \\
\text { Rock }\end{array}$ \\
\hline$<2 \mu \mathrm{m}$ & Clay & 70.67 & 21.80 \\
$2 \mu \mathrm{m}-20 \mu \mathrm{m}$ & Silt & 27.56 & 22.82 \\
$>20 \mu \mathrm{m}$ & Sand & 1.77 & 55.38 \\
\hline
\end{tabular}

The clayey material had a high percentage of clay, which gave it a very high plasticity. In this case, a considerable amount of water was required to form a workable plastic mass. Due to the high concentration of the clay fraction $(<2 \mu \mathrm{m})$ in the sample, a high degree of packing occurs, making the water very difficult to remove during drying. In these cases, there is an increase in the moisture gradient inside the parts, causing severe retractions and deformations in the materials [1]. To prevent this, these authors suggest a combination of such materials with others considered non-plastic, such as sand, mica and iron oxides. In this sense, the sedimentary rock is a material with a significant amount of non-plastic component (sand) and can be added to the clay material to reduce the plasticity of the material. A high concentration of sand also increases the amount of intergranular pores, which in turn, allow the elimination of water during the drying process. Thus, changes occur in the characteristics of the plastic material and therefore the final product.

As shown in Table II, the clay material had a typical composition of the kaolinite group, with a low percentage of oxide fluxes and high $\mathrm{Al}_{2} \mathrm{O}_{3}$ content. The low percentage of $\mathrm{SiO}_{2}$ and higher loss on ignition were associated with a higher percentage of clay, which reinforced the textural analysis results. Besides the major common components ( $\mathrm{Si}$ and $\mathrm{Al}$ ) in clay minerals, iron and titanium oxides show the highest concentrations among the minor components. Iron oxides enhance the action of alkaline flux, causing melting at lower temperatures and more abundant liquid phases. Titanium acts as intermediary element and may contribute to forming or modifying the glassy network of materials. Thus, titanium is a nucleating agent that can influence the crystallization of new phases. The incorporation of the rock would lower the concentration of titanium in the mixture.

The sedimentary rock showed a higher percentage of fluxing oxides than did the clayey material. The oxides $\mathrm{Na}_{2} \mathrm{O}$ and $\mathrm{K}_{2} \mathrm{O}$ are fluxes present in the rock due to the occurrence of mainly feldspars and micas. In general, the amount of $\mathrm{K}_{2} \mathrm{O}$ in clays is higher than the amount of $\mathrm{Na}_{2} \mathrm{O}$, because micaceous minerals are more resistant to weathering. The alkaline compounds $\mathrm{K}_{2} \mathrm{O}$ and $\mathrm{Na}_{2} \mathrm{O}$ give rise to liquid phase,
Table II - Chemical composition of samples.

\begin{tabular}{ccc} 
[Tabela II - Composição química das amostras.] \\
\hline & $\begin{array}{c}\text { Clayey } \\
\text { Material }\end{array}$ & $\begin{array}{c}\text { Sedimentary } \\
\text { Rock }\end{array}$ \\
\hline $\mathrm{SiO}_{2}$ & 48.82 & 68.5 \\
$\mathrm{Al}_{2} \mathrm{O}_{3}$ & 27.64 & 11.3 \\
$\mathrm{Fe}_{2} \mathrm{O}_{3}$ & 5.64 & 5.8 \\
$\mathrm{Na}_{2} \mathrm{O}$ & 0.01 & 0.5 \\
$\mathrm{~K}_{2} \mathrm{O}$ & 1.96 & 3.6 \\
$\mathrm{CaO}$ & 0.16 & 0.5 \\
$\mathrm{MgO}$ & 0.58 & 2.54 \\
$\mathrm{MnO}$ & 0.02 & 0.12 \\
$\mathrm{TiO}_{2}$ & 3.38 & 0.97 \\
$\mathrm{P}_{2} \mathrm{O}_{5}$ & 0.07 & $<0.1$ \\
$\mathrm{PF}$ & 11.5 & 6.41 \\
\hline
\end{tabular}

making crystallization difficult, which tends to remain in the sintered body as glassy phases [10]. The ions $\mathrm{Na}^{+}, \mathrm{K}^{+}$, $\mathrm{Ca}^{2+}$ and others are called modifiers, because they enter the interstices of the lattice of the glass, weaken the connections and cause a decrease in melting temperature, facilitating the formation of glass [11]. $\mathrm{MgO}$ may indicate traces of smectite or micaceous clay minerals. $\mathrm{CaO}$ together with $\mathrm{MgO}$ act as network modifiers and tend to lower the refractoriness of clays. Usually, they come from calcite, dolomite and gypsum and are rarely found in the refractory type kaolinitic clays.

In rock, the percentage of $\mathrm{Al}_{2} \mathrm{O}_{3}$ and loss on ignition were lower and the concentration of $\mathrm{SiO}_{2}$ was much higher compared to the clayey material. This was due to the rock's higher content of sand-silt fractions. In both materials, iron oxides were the third component with the highest concentration $(>5 \%)$. Like $\mathrm{TiO}_{2}, \mathrm{Fe}_{2} \mathrm{O}_{3}$ is a mineralizer that promotes or antecipates the nucleation and crystallization of mullite, as well as, the formation of the glassy phase which promotes the sintering of ceramics [3]. These two oxides can darken the glassy phase. It was observed (Fig. 1) that the higher the concentration of the rock in the sample, the higher the concentration of the vitreous phase was, as could be seen at a temperature of $1100{ }^{\circ} \mathrm{C}$.

In the X-ray pattern of the clayey material (Fig. 2), the following minerals were identified: quartz, clay minerals of the kaolinite group, mica/illite, gibbsite, goethite and rutile. This mineralogical composition is common in soils and clays of western São Paulo State [12]. The X-ray diffractograms (insert Fig. 2) of the oriented and saturated samples (with potassium and magnesium) showed diffraction peaks that indicated the presence of some clay minerals (kaolinite $(\mathrm{K})$, illite mica (I) and 2:1 clay, probably montmorillonite), quartz and gibbsite. This predominance of clay minerals (kaolinite and mica) is also observed in the $\mathrm{SiO}_{2} / \mathrm{Al}_{2} \mathrm{O}_{3}$ ratio (1.77) in the chemical analysis data of the clayey material [13].

The X-ray pattern of the sedimentary rock is shown in Fig. 3. The diffraction peaks of crystalline phases show a predominance of quartz $\left(\mathrm{SiO}_{2}\right)$ and mica/illite. There are 


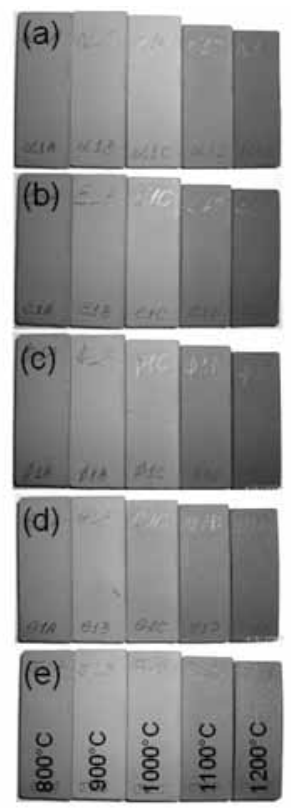

Figure 1: Images of the sintered probes: (a) clayey, (b) 20 wt. $\%$ rock, (c) $40 \mathrm{wt} . \%$ rock, (d) $60 \mathrm{wt} . \%$ rock, and (e) $80 \mathrm{wt} . \%$ rock. [Figura 1: Imagens dos corpos de prova sinterizados: (a) material argiloso, (b) $20 \%$ rocha; (c) $40 \%$ rocha, (d) $60 \%$ rocha e (e) $80 \%$ rocha.]

also peaks indicating the presence of kaolinite with low crystallinity, goethite and rutile. This result was consistent with the chemical analysis data, showing a high silica/ alumina ratio and potassium concentration.

The clay fraction of the rock was saturated with potassium and magnesium and then oriented on glass slides and analyzed. The XRD patterns (Fig. 3, insert) show that there was a predominance of mica/illite $\left(8.5^{\circ}(10 \AA), 17.6^{\circ}\right.$ (5 $\AA$ ) and $26.6^{\circ}(3.3 \AA)$ ). The third-order peak of mica coincides with the peak of quartz, which was also present in the rock. The shoulder to the left of the first order peak $\left(8.5^{\circ}(10 \AA)\right)$, indicates the presence of inter-stratified clay

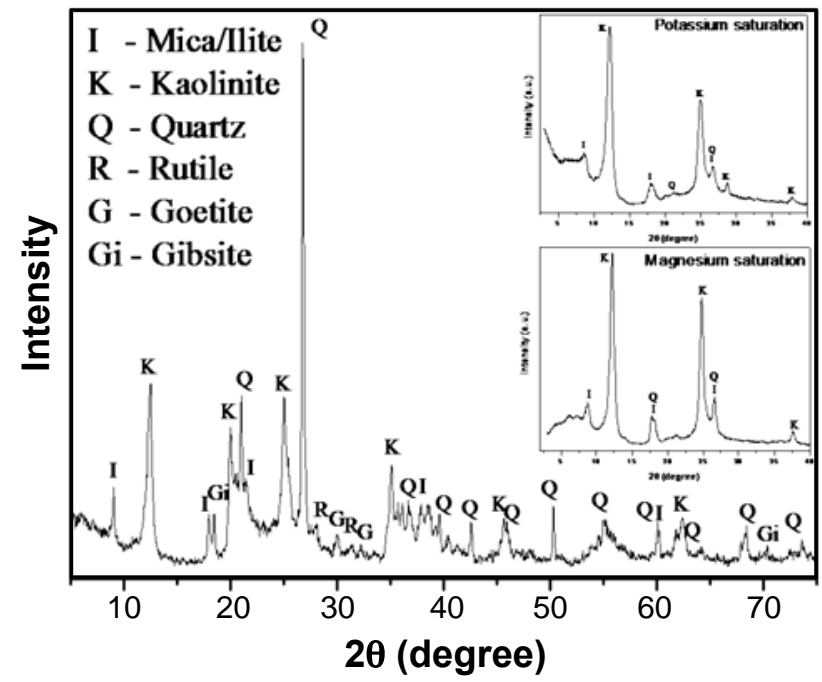

Figure 2: XRD of natural clayey material powder.

[Figura 2: DRX do material argiloso natural em pó.]

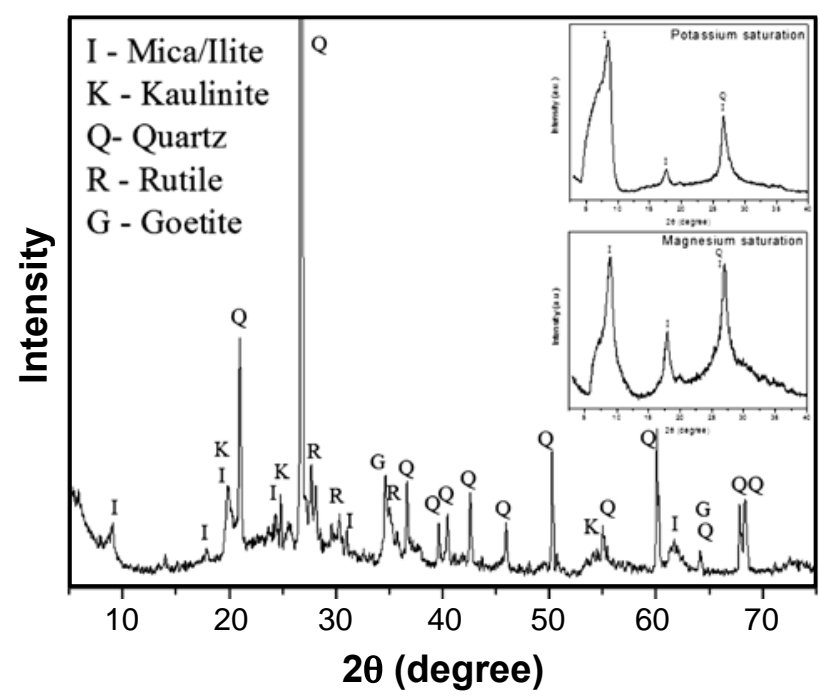

Figure 3: XRD of natural sedimentary rock powder.

[Figura 3: DRX do da rocha sedimentar natural em pó.]

mineral illite/smectite, which is the mixed layer clay mineral most abundant and common in sedimentary rocks and soils [14].

Fig. 4 shows the thermogravimetric analysis (TG and DTG) for the clayey material. In the temperature range of $60{ }^{\circ} \mathrm{C}$ to $100{ }^{\circ} \mathrm{C}$, there was a small loss of mass corresponding to the elimination of free water between the particles. When this water is removed, the particles coalesce (due to capillary forces), causing contraction of the material. Another significant mass loss occurred around $256{ }^{\circ} \mathrm{C}$ due to the combustion of organic matter, water loss from hydroxides (e.g., goethite and gibbsite) and loss of water coordinated with cations of 2:1 clay minerals. Around 475 ${ }^{\circ} \mathrm{C}$, there was a greater loss of mass due to the dissociation of constitution water (or structural water), i.e., comprising the hydroxyl group of the kaolinite clay mineral.

Differential thermal analysis (DTA) of the clay material (Fig. 5) confirmed the presence of hydroxides (endothermic peak around $280^{\circ} \mathrm{C}$ ), as seen in the TG and XRD results. The loss of the kaolinite hydroxyls was also observed at $513^{\circ} \mathrm{C}$.

The DTA data of the sedimetary rock showed

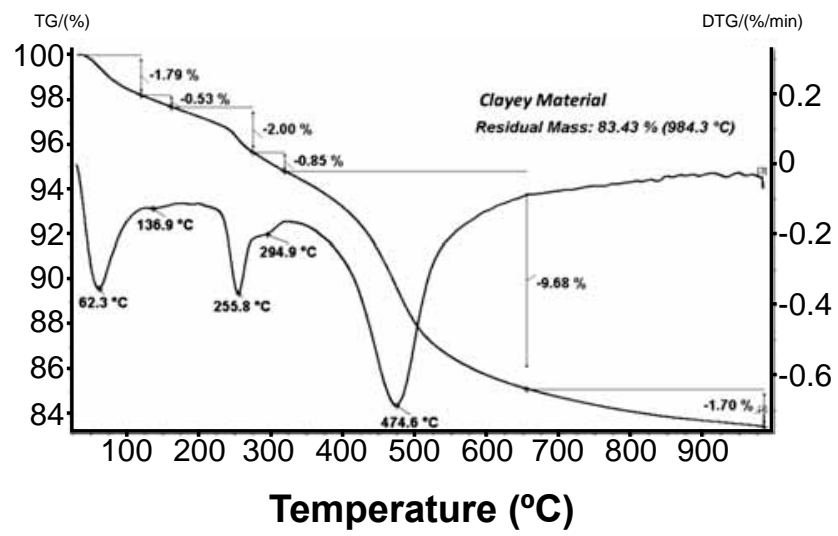

Figure 4: TG and DTG curves of the clayey material.

[Figura 4: Curvas TG e DTG do material argiloso.] 
an endothermic peak with a maximum at $499{ }^{\circ} \mathrm{C}$, corresponding to the loss of structural water (hydroxyl) of iron-rich smectite [2]. As the rock generally had a low concentration of kaolinite, the endothermic peak of the loss of hydroxyl must have overlapped that of smectite. A greater enhancement of this peak was seen the clay sample, which had a larger amount of kaolinite (observed in the chemical analysis and XRD), compared to the rock. The endothermic peak at temperatures below $300{ }^{\circ} \mathrm{C}$ was associated with the loss of adsorbed water of the exchangeable cations (between layers) of 2:1 clay and hydroxyls of iron and aluminum hydroxides. The loss of the hydroxyls of kaolinite results in the formation of an unstable phase, called metacaulinita. At $964{ }^{\circ} \mathrm{C}$, an exothermic peak appeared in DTA of the clay material, which corresponded to the crystallization of the existing metaphase, leading to the nucleation of mullite. The same was true for the sedimentary rock at $947{ }^{\circ} \mathrm{C}$ due to the presence of kaolinite and mica [15].

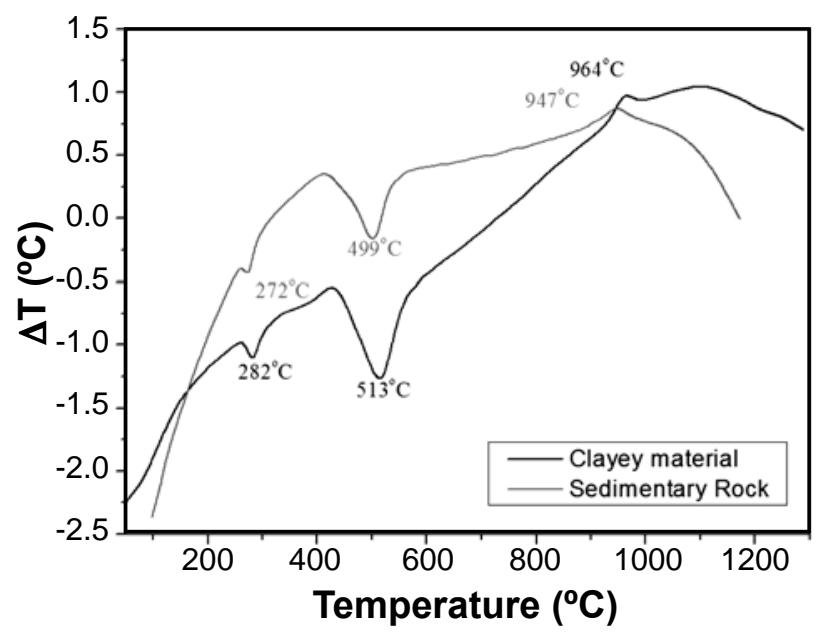

Figure 5: DTA curves of the clay material and sedimentary rock. [Figura 5: Curvas de DTA do material argiloso e rocha sedimentar.]

The TG and DTG analysis of sedimentary rock sample (Fig. 6) showed a significant loss of mass in a temperature range up to $100{ }^{\circ} \mathrm{C}$, which corresponded to the loss of moisture between the particles, as occurred with the sample of clayey material. Due to its mineralogical composition, predominantly mica with kaolinite and 2:1 clays, a small mass loss was observed near $500{ }^{\circ} \mathrm{C}$, associated with the last two clay minerals, and a continuous loss of mass up to $980{ }^{\circ} \mathrm{C}$ due to loss of hydroxyls from mica. Unlike kaolinite, illite does not lose all of its hydroxyl in a small temperature range. This occurs slowly over a wide temperature range above $600{ }^{\circ} \mathrm{C}$.

The description of the high temperature phases and metaphases to montmorillonite and illite is more difficult than for the case of kaolinite due to the chemical composition of these minerals being much more variable [3]. These two 2:1 type clay minerals are the main components of sedimentary rock.

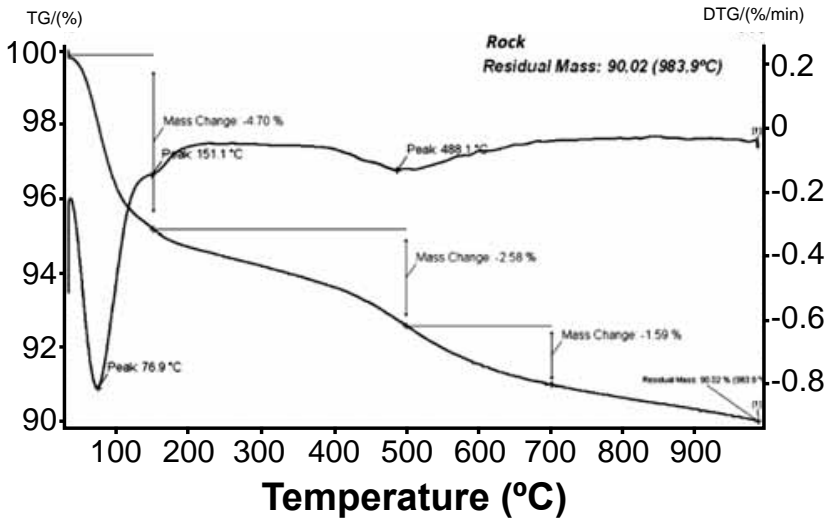

Figure 6: TG and TG curves of sedimentary rock.

[Figura 6: Curvas de TG e TG da rocha sedimentar.]

\section{Characterization: clayey material with sedimentary rock}

Information provided by the curves in Fig. 7A helped understand the changes in the ceramic probe during heating due to the influence of sedimentary rock incorporation. The loss of hydroxyls from kaolinite and smectite clay was slightly decreased with the rock incorporation, as can be seen in the small variation of the endothermic peak around $500{ }^{\circ} \mathrm{C}$. Moreover, the characteristic peak of the quartz $\alpha-\beta$ structural transformation was more evident in the samples with higher rock concentrations ( $40 \%$ and $60 \%$ ). The addition of rock also increased the concentrations of mica/illite and 2:1 clay mineral, resulting in a small endothermic peak near $881{ }^{\circ} \mathrm{C}$ (Fig. 7B), corresponding to the breaking of mica and smectite structures [2]. This peak was more evident in the samples with $60 \mathrm{wt} \%$ rock. Besides, the exothermic peak that characterizes the nucleation of mullite was less defined with the incorporation of the rock. This finding is explained by the increased concentration of crystalline $\mathrm{SiO}_{2}$ and decrease in kaolinite and, consequently, alumina. At $1065^{\circ} \mathrm{C}$ (Fig. 7B), a small endothermic peak was seen for the content of 20 wt.\% rock, which characterizes the formation of a liquid phase promoted by the oxides in sedimentary rock. However, this peak was not observed for rock contents of 40 and $60 \mathrm{wt} \%$. The formation of the first liquid phase depends on the $\mathrm{Al} / \mathrm{Si}$ and $\mathrm{K} / \mathrm{Al}$ ratios, which can move the fusion endothermic peak to other regions in the thermogram [16].

Fig. 8 shows the diffractograms for the clayey material, without residue, sintered at various temperatures $\left(500{ }^{\circ} \mathrm{C}\right.$ $1200{ }^{\circ} \mathrm{C}$ ). The pattern of the natural clay shows that kaolinite is the major phase. At $500{ }^{\circ} \mathrm{C}$, as expected, their characteristic diffraction peaks disappeared due to the loss of hydroxyl groups. This reaction broke the bonds between the silicon tetrahedral and aluminum octahedral, destroying their laminar structure, transforming kaolinite into metakaolinite. Up to approximately $900{ }^{\circ} \mathrm{C}$ the $\mathrm{OH}$ groups of illite and montmorillonite were gradually removed, making these phases disappear in the XRD patterns. Above $900{ }^{\circ} \mathrm{C}$, in addition to the disappearance of the peaks of illite/mica, diffraction peaks were observed, characteristic of mullite 

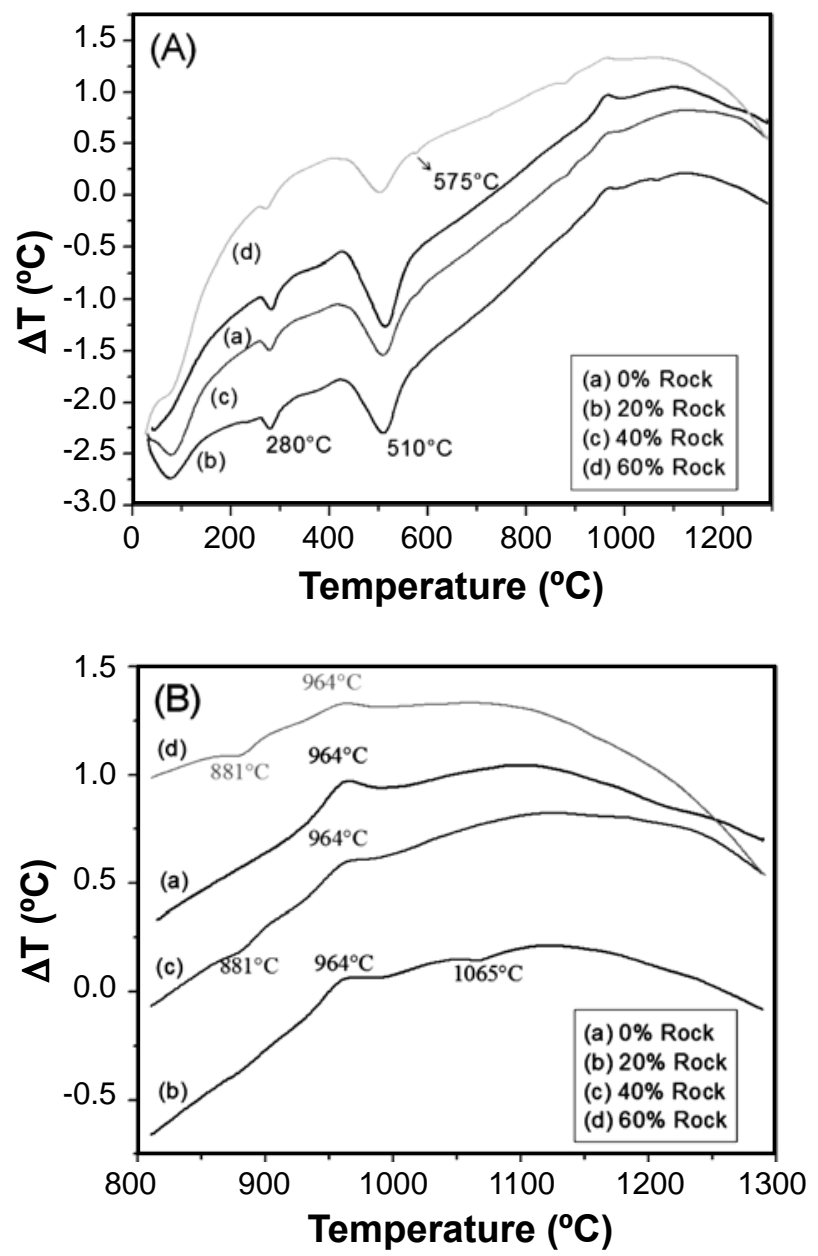

Figure 7: (A) DTA curves of the clay samples with sedimentary rock; (B) DTA thermograms in the temperature range $800{ }^{\circ} \mathrm{C}-1300{ }^{\circ} \mathrm{C}$.

[Figura 7: A) Curvas de DTA da amostra de argila com rocha sedimentar; (B) curvas de DTA da amostra de argila com rocha sedimentar entre $800{ }^{\circ} \mathrm{C}$ e $1300^{\circ} \mathrm{C}$.]

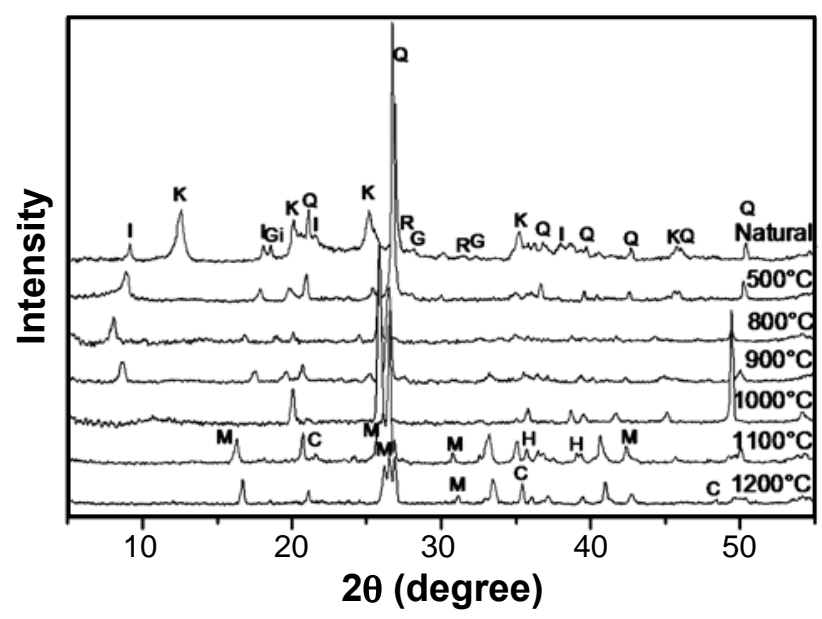

Figure 8: X-ray diffraction patterns of clayey material: I - Mica/ Ilita, K - Kaolinite, Gi - Gibbsite, Q - Quartz, R -Rutile, G Goethite, M -Mullite, C - Cristobalite, $\mathrm{H}$ - Hematite.

[Figura 8: Difratogramas de raios $X$ do Material Argiloso: I Mica/Ilita; K-Caulinita; Gi-Gibsita; $Q$-Quartzo; $R$-Rutilo; G-Goetita; M - Mulita; C - Cristobalita; H - Hematita.]
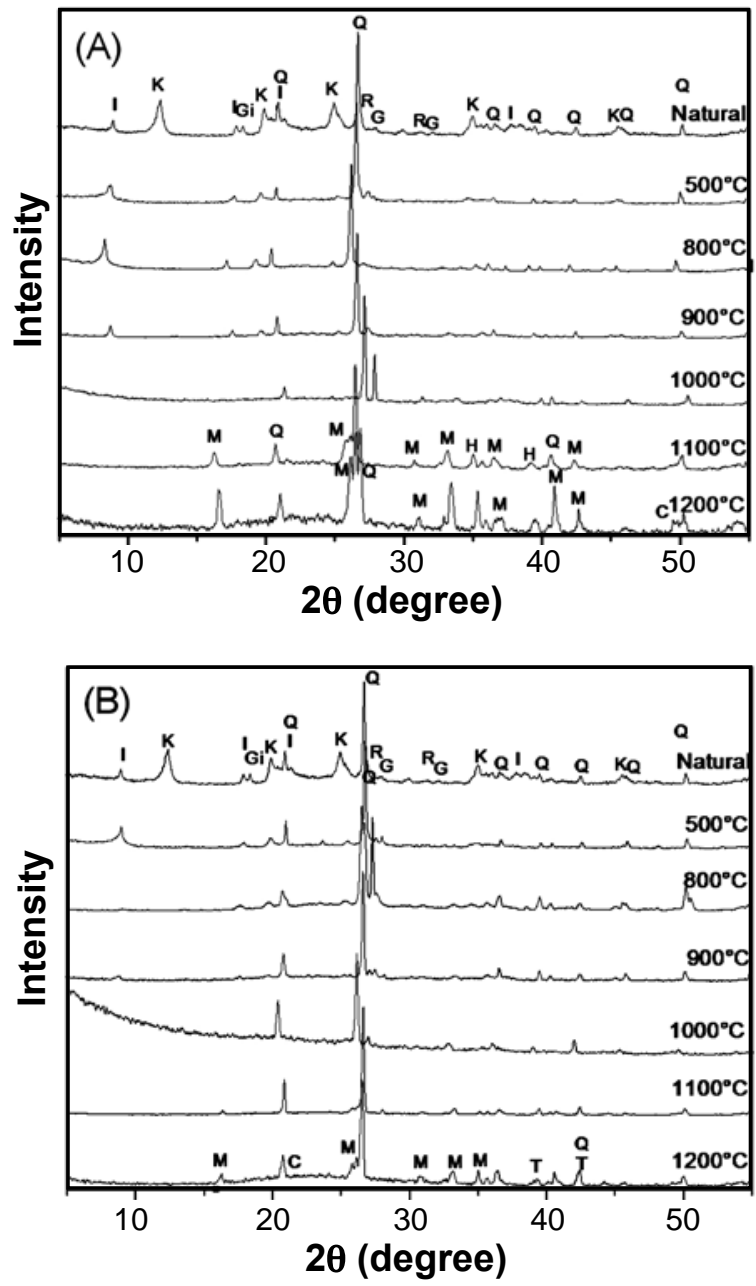

Figure 9: X-ray diffraction patterns of clayey material with (A) $20 \%$ sedimentary rock and (B) 60\% sedimentary rock: I - Mica/Ilita, K - Kaolinite, Gi - Gibbsite, Q - Quartz, R - Rutile, G - Goethite, $\mathrm{M}$ - Mullite, C - Cristobalite, $\mathrm{H}$ - Hematite, $\mathrm{T}$ - Tridymite, $\mathrm{F}$ Feldspar.

[Figura 9: Difratogramas de raios $X$ do material argiloso com (A) 20\% de Rocha Sedimentar; (B) 60\% de Rocha Sedimentar: IMicalIlita; K-Caulinita; Gi-Gibsita; Q-Quartzo; R-Rutilo; G-Goetita; $M$ - Mulita; C - Cristobalita; H - Hematita; $T$ Tridimita.]

and cristobalite formation. As a consequence, a reduction in the intensities of the quartz peaks was observed. The peak doublet around $26^{\circ}(2 \theta)$ indicates the formation of orthorhombic mullite [17]. In this temperature range, the peaks corresponding to hematite were also identified, which may have been formed from iron hydroxides, such as goethite, and from iron released during the break of the structures of some clay minerals (smecttites and illite have isomorphic substitution of $\mathrm{Al}$ by $\mathrm{Fe}$ in its octahedral layer) [18]. The XRD pattern at $500{ }^{\circ} \mathrm{C}$ showed the disappearance of the iron and aluminum hydroxide (goethite and gibbsite) peaks, which are common in this type of clay minerals. These reactions were observed in the DTA thermograms (Fig. 7A) around $270{ }^{\circ} \mathrm{C}$.

Figs. 9A and B show the diffractograms of clayey 
material with 20 and $60 \mathrm{wt} . \%$ rock, respectively. The results show that the structural changes of kaolinite and mica occur at temperatures as low as that observed in the natural sample, subjected to the same temperatures. The incorporation of $20 \%$ of sedimentary rock aided the formation of potassium aluminum silicates (feldspar - $\mathrm{KAlSi}_{3} \mathrm{O}_{8}$ ) characterized by the thin peak around $27^{\circ}$ in the sample sintered at $1000{ }^{\circ} \mathrm{C}$. This can be explained by the decomposition of mica and consequent potassium release which reacts with amorphous alumina arising from the decomposition of kaolinite for the formation of this feldspar. The characteristic peak of this phase disappeared at higher temperatures, because in addition to behaving as a flux, feldspar contributes to the formation of mullite. With a content of $60 \%$ sedimentary rock, the feldspar XRD peak was less evident, because the silica and amorphous alumina released from the low content of kaolinite is not sufficient to react with potassium originating from the decomposition of mica to form feldspar. The nucleation of mullite was observed starting at $1100{ }^{\circ} \mathrm{C}$ when the peaks that characterize the quartz began to decrease. The addition of $60 \mathrm{wt} . \%$ rock hindered the formation of mullite due to the high concentration of quartz and the low content of kaolinite, which was the mainly responsible for mullite formation. However, the rock contributed to the formation of other phases, such as tridymite, which can form starting at $1200{ }^{\circ} \mathrm{C}$. When quartz is maintained above $870{ }^{\circ} \mathrm{C}$ for a long time it slowly transforms into tridymite, which in turn, changes to cristobalite above $1470{ }^{\circ} \mathrm{C}$. These changes require a greater rearrangement of the structure, with some bonds being broken and others being formed. Impurities, such as iron oxide, tend to distort the lattice of crystalline silica and accelerate these transformations [19].

\section{Physical and mechanical properties}

Fig. 10 shows the linear shrinkage and water absorption of the pieces with increasing sintering temperature. In general, the retraction parameter of the ceramic bodies tended to increase with temperature. It was observed that at $800{ }^{\circ} \mathrm{C}$ and $900{ }^{\circ} \mathrm{C}$, there was little change in linear shrinkage of pieces, indicating that in this temperature range, the process of pores closing was incipient. However, above $1000{ }^{\circ} \mathrm{C}$, significant changes in linear shrinkage occurred. This change was mainly due to the formation of the liquid phase, which partially fills the pores between particles, thereby promoting the shrinkage and densification of the bodies. The rock addition caused a decrease in linear shrinkage of the ceramic pieces due to the increase in the quartz concentration. For $60 \mathrm{wt} . \%$ and $80 \mathrm{wt} . \%$ rock added, the ceramic pieces expanded at $800{ }^{\circ} \mathrm{C}$. Starting at $1000{ }^{\circ} \mathrm{C}$, there was considerable variation in linear shrinkage for all samples, which decreased with concentration of rock. This shrinkage with temperature can also be observed in the images shown in Fig. 1.

As expected, water absorption (Fig. 10) decreased with increasing sintering temperature. Furthermore, water absorption was also lower with higher concentration of rock added, in the temperature range of $800-1000{ }^{\circ} \mathrm{C}$. Although, the water absorption appeared to rise with concentration of rock, between 1100 and $1200{ }^{\circ} \mathrm{C}$, it remained practically the same for all samples, considering the standard deviation in the measurements. The presence of fluxing oxides in the rock aided the formation of the liquid phase, while the quartz added decreased the retraction and water absorption of the ceramic pieces. However, during sample cooling, the silicates (quartz, tridymite and cristobalite) undergo phase transition at temperatures below $600{ }^{\circ} \mathrm{C}$ and can produce cracks and closed pores in the glassy phase deposited around the grains of quartz. This effect was greater with higher concentration of rock, mainly for the samples sintered at 1000 and $1100{ }^{\circ} \mathrm{C}$. For those sintered at $1200{ }^{\circ} \mathrm{C}$, this effect was minimized due to the lower quartz concentration (XRD), which was associated with the formation of new phases (mullite and other silicates). At this temperature, the liquid phase is more abundant and less viscous, which acts on a greater sample volume, diminishing the porosity of the sample.

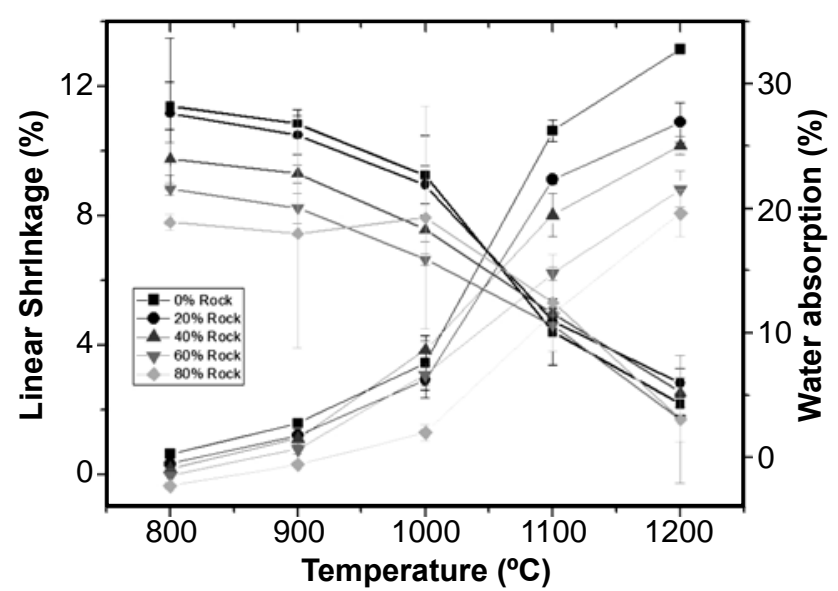

Figure 10: Linear shrinkage and water absorption as a function of temperature for samples with sedimentary rock.

[Figura 10: Retração linear de queima e absorção d'água em função da temperatura para as amostras com rocha sedimentar.]

Apparent specific mass and apparent porosity (Fig. 11) followed the same behavior as water absorption and linear shrinkage. The changes in these parameters were small from $800{ }^{\circ} \mathrm{C}$ to $900{ }^{\circ} \mathrm{C}$ and became more intense above $1000{ }^{\circ} \mathrm{C}$. Starting at this temperature, the apparent density of the samples increased and consequently porosity decreased with the addition of rock. This behavior was different at higher temperatures $\left(1100{ }^{\circ} \mathrm{C}\right.$ and $\left.1200{ }^{\circ} \mathrm{C}\right)$, at which the apparent specific mass of pieces with rock decreased and the porosity assumed similar values for all concentrations. The densification of the samples was determined by changes in their microstructure during firing, which are associated mainly with the formation of liquid phases and other crystalline phases.

The flexural strength of the ceramic bodies in relation to firing temperature and concentration of added rock is shown in Fig. 12. It can be seen that flexural strength increased with 


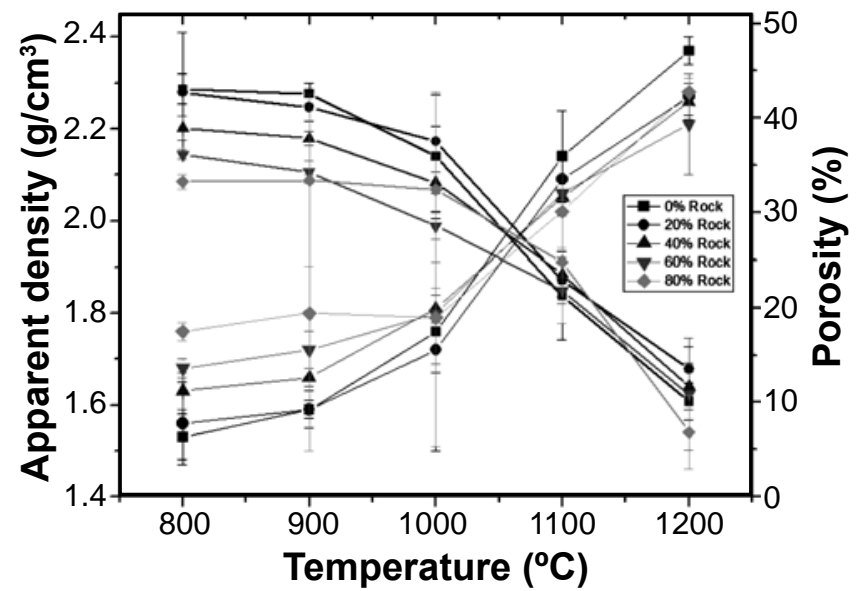

Figure 11: Apparent density and porosity as a function of temperature for samples with sedimentary rock.

[Figura 11: Massa específica aparente e porosidade aparente em função da temperatura para amostras com rocha sedimentar.]

temperatures above $1000{ }^{\circ} \mathrm{C}$. This occurred due to the denser, low-porosity material obtained at these temperatures. The flexural strength data agree with the other data presented, which defined the temperature of $1000{ }^{\circ} \mathrm{C}$ as a changing point in the sintering process. It was also observed that the addition of sedimentary rock decreased the flexural strength values. The reason for this was related to quartz particles of the rock added to the samples. The quartz acts as fracture initiation sites, because it does not participate in the ceramic sintering process at lower temperatures. However, above $1000{ }^{\circ} \mathrm{C}$, there was a decrease in the quartz peak intensities with the appearance of peaks corresponding to tridymite and mullite. Although the rock addition decreased the flexural strength, the results show that for any percentage of rock, this parameter was greater than $2.0 \mathrm{MPa}$, even for $800{ }^{\circ} \mathrm{C}$. This is the limit value for ceramic bricks (Table III). The flexural strength increased with temperature up to values of around $30 \mathrm{MPa}\left(20 \mathrm{wt} \%\right.$ rock at $\left.1200^{\circ} \mathrm{C}\right)$. The incorporation

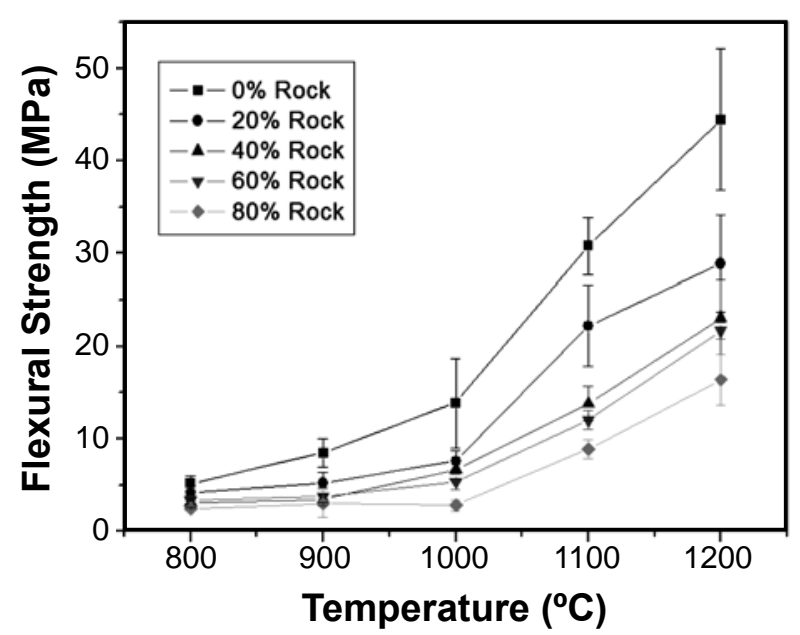

Figure 12: Flexural strength as a function of temperature for samples with sedimentary rock.

[Figura 12: Módulo de ruptura à flexão em função da temperatura para amostras com rocha sedimentar.] of 80 wt.\% rock, sintered at $1200{ }^{\circ} \mathrm{C}$, had a flexural strength of around $18 \mathrm{MPa}$.

Although the addition of sedimentary rock worsened some physical parameters, they were still in accordance with the standards established for Brazilian ceramic materials [2], as shown in Table III. New values for some of these limits were established by ABNT (Associação Brasileira de Normas Técnicas) [20, 21]. Limit values to total linear shrinkage, apparent specific mass and apparent porosity are: $<6 \%,>1.6 \mathrm{~g} / \mathrm{cm}^{3}$ and $<35 \%$, respectively.

\section{CONCLUSION}

Sedimentary rock has a composition that permits its utilization as non-plastic material to control the plasticity of raw material used to produce ceramic pieces. Besides the high concentration of quartz, it has some fluxing oxides and clay minerals such as mica and smectites, which can also help in the sintering process. The addition of sedimentary rock inhibits the formation of mullite, because it reduces the concentration of clay minerals and, consequently, amorphous silica and alumina, originating principally from the decomposition of kaolinite. Below $1000{ }^{\circ} \mathrm{C}$, added sedimentary rock improves all ceramic properties (linear shrinkage, water absorption, apparent specific mass and apparent porosity) except flexural strength. During the cooling process, the quartz phase inversion, new crystalline phases, and the different thermal retraction of the crystalline phases in the glassy phase may contribute to the production of tension and microcracks, decreasing the mechanical strength of the material. With the rock addition, the apparent density shows a behavior compatible with the porosity. The great decline in flexural strength, indicates that the microcracks are equivalent to closed porosity, i.e., decreases considerably the flexural strength, but does not increase the water absorption in the same way. The mechanical test results showed that the addition of rock (till $80 \mathrm{wt} . \%$ ) to the ceramic material is feasible for the production ceramic pieces within the limits established by Brazilian standards.

\section{ACKNOWLEDGEMENTS}

The authors thank to Cerâmica Romana and Mr. José Fredi by the raw material samples. Ms. Madalena and LIEC/S. Carlos are also acknowledged by X-ray diffraction analysis.

\section{REFERENCES}

[1] S. Pracidelli, F. G. Melchiades, Cerâmica Industrial 2 (1997) 31.

[2] P. S. Santos, Ciência e Tecnologia de Argilas, $2^{\mathrm{a}}$ Ed., Ed. Edgard Blücher Ltda., Vol. 1, S. Paulo, Brasil (1989).

[3] C. F. Gomes, Argilas: O que são e para que servem, Fundação Caloustre Gulbenkian, Lisboa (1988).

[4] A. K. Chakravorty, K. G. Dilip, J. Am. Ceram. Soc. 74 (1991) 1401. 
[5] H. S. Santos, P. Kiyohara, A. C. V. Coelho, P. S. Santos, Cerâmica 52, 322 (2006) 125.

[6] C. C. Osawa, "Efeito do pH e da uréia na síntese de mulita pelo método sol-gel, a partir de sóis de sílica e alumina", Diss. Mestrado, Universidade Estadual de Campinas Unicamp, Campinas, SP, Brasil (2004).

[7] A. C. Moniz, A. Carvalho, Rev. Cient. Inst. Agrôn. Est. S. Paulo 32, 17 (1973) 309.

[8] L. Sánchez-Muñoz, S. S. Cava, C. A. Paskocimas, E. Cerisuelo, E. Longo, J. B. Carda, Cerâmica 48, 306 (2002) 108.

[9] C. M. F. Vieira, H. F. Sales, S. N. Monteiro, Cerâmica 50, 315 (2004) 239.

[10] R. R. Menezes, A. M. Segadães, H. S. Ferreira, H. C. Ferreira, Cerâmica 49, 310 (2003) 72.

[11] K. R. Ferrari, P. M. Figueiredo Filho, L. A. Machado, J. O. A. Paschoal, "Transformações das Matérias-Primas do Suporte Durante a Queima de Revestimento Cerâmico", Cerâmica Industrial 5, 2 (2000) 53.

[12] S. R. Teixeira, S. A. Souza, C. A. I. Moura, "Mineralogycal Characterization of Clays Used in the Structural Ceramic Industry in West of S. Paulo State, Brazil", Cerâmica 47, 304 (2001) 204.

[13] G. P. Souza, S. J. G. Sousa, L. A. H. Terrones, J. N. F. Holanda, "Mineralogical Analysis of Brazilian Ceramic
Sedimentary Clays Used in Red Ceramic", Cerâmica 51, 320 (2005) 382.

[14] D. M. Moore, R. C. Reynolds Jr., X-Ray Diffraction and the Identification of Clay Minerals, $2^{\text {nd }}$ Ed., Oxford University Press, New York, USA (1997) p. 378.

[15] G. P. Sedmale, I. É. Shperberga, U. Ya. Sedmalis, "Formation of Mullite Base don Hydromica Clay Aluminum Oxide Composition", Glass Ceramics 61, 1-2 (2004) 48.

[16] A. M. Segadães, M. A. Carvalho, H. C. Ferreira, "Using Phase Diagrams to Deal With Moisture Expansion", Ceram. Int. 29 (2003) 947.

[17] C. C. Osawa, C. A. Beltran, "Mullite Formation from Mixtures of Alumina and Silica Sols: Mechanism and $\mathrm{pH}$ Effect", J. Braz. Chem. Soc. 16, 2 (2005) 251.

[18] J. B. Dixon, G. N. White, Soil Mineralogy Laboratory Manual. Soil \& Sciences Department, Texas A \& M University, College Station, Texas, USA (1996).

[19] F. H. Norton, Introdução à Tecnologia Cerâmica, Edgard Blücher, S. Paulo, Brasil (1973).

[20] ABNT NBR 15270-2, Componentes cerâmicos Parte 2: Blocos cerâmicos para alvenaria estrutural - Terminologia e requisitos (2005).

[21] ABNT NBR 15310, Componentes cerâmicos - Telhas Terminologia, requisitos e métodos de ensaio (2009).

(Rec. 10/05/2012, Ac. 26/05/2012) 